\title{
Value Theory in the Economics of Sustainable Development
}

\section{Teoria wartości w ekonomii rozwoju zrównoważonego}

\author{
Małgorzata Pink \\ University of Agriculture in Kraków, \\ al. Mickiewicza 21, 31-120 Kraków, Poland \\ E-mail malgorzata.pink@urk.edu.pl
}

\begin{abstract}
Historically, the value theory was based on an objectivist approach, where the value of the goods arises through the involvement of private means of production, with a special role of work or a subjectivist approach, where value is a subjective phenomenon and depends on marginal utility of the economic entity. The neoclassical revolution replaced the vague value theory with price theory, the economic reality and consumer expectations led to a situation in which lowering the price of goods at the expense of the environment became a commonly accepted mode of operation. For a long time, the value theory in economics was not an area of reflection, both in the sense of economic and moral value. It was assumed that the subjective character of the value phenomenon makes the analysis of value elusive for the tools of economics. At the same time, environmental goods were considered to be socalled free, occurring in unlimited quantities. These assumptions have contributed to the development of an economics theory that is the antithesis of the economics of sustainable development, excessively exploiting the environment and, indirectly, society as well. The assumptions of sustainable development redefine the space for interpretation of the value theory and imply a change in the approach to an environmental element that cannot be understood in the sense of a free good and which imposes an objective understanding of values that can be preserved or lost in the production process.
\end{abstract}

Key words: theory of value, sustainable development, value, price

\section{Streszczenie}

Historycznie, teoria wartości opierała się na obiektywistycznym podejściu, gdzie wartość dobra powstaje poprzez zaangażowanie prywatnych środków produkcji, ze szczególną rolą pracy lub też subiektywistycznym podejściu, gdzie wartość jest zjawiskiem o subiektywnym charakterze i zależna jest od użyteczności krańcowej podmiotu gospodarującego. Neoklasyczna rewolucja zastąpiła niejasną teorię wartości teorią ceny, rzeczywistość gospodarcza i oczekiwania konsumentów doprowadziły do sytuacji, w której obniżanie ceny dóbr kosztem środowiska, stało się powszechnie przyjętym sposobem działania. Przez długi okres teoria wartości w ekonomii nie stanowiła obszaru rozważań, zarówno w znaczeniu wartości ekonomicznej, jak i moralnej. Przyjęto, że subiektywny charakter zjawiska wartości czyni analizę wartości nieuchwytną dla narzędzi ekonomii. Jednocześnie dobra środowiskowe uznawane były za tzw. wolne, występujące w nieograniczonych ilościach. Te założenia przyczyniły się do rozwoju gospodarki będącej antytezą ekonomii rozwoju zrównoważonego, nadmiernie eksploatującej środowisko, a pośrednio również społeczeństwo. Założenia rozwoju zrównoważonego otwierają na nowo przestrzeń do interpretacji teorii wartości i implikują zmianę podejścia do elementu środowiskowego, którego nie można rozumieć już w znaczeniu dobra wolnego, i który narzuca obiektywne rozumienie wartości, która w procesie produkcji może zostać zachowana lub utracona. 


\section{Introduction}

The aim of this article is to try to develop the problems of value theory in the context of the assumptions of the economics of sustainable development. The value theory has traditionally been one of the main areas of economic reflection. The inability to find a consensus as to the sources of the value of goods, or even its very existence, led to the replacement of the value theory with the theory of price. The assumptions of the neoclassical school economic model $^{1}$, have made economics (seemingly) amoral ${ }^{2}$. Understanding the value theory in mainstream economics is based on a marginalist theory, where value is a subjective phenomenon. The subjectivity understood in utilitarian terms in the world of economics has led to unprecedented economic development, but also to proportional exploitation of natural resources, the profits of which have not been and are not shared in a fair manner ${ }^{3}$; which also has an impact on the social aspect of reality. The economics of sustainable development opens the space for the resumption of this debate. In addition to the signalled attempt to formulate a value theory that is part of the sustainable development assumption, this article will also set questions about the subjective nature of the value of goods and services and the legitimacy of determining selected natural resources as free goods. Sustainable development for the purposes of the article is defined and understood in accordance with the 1987 report of the Brundtland Commission, as: development that meets the today's needs, without prejudice to the ability of future generations to meet their own needs. It contains two key concepts:

- the concept of 'needs', in particular the basic needs of the poor in the world, which should be given the overriding priority;

- the concept of limitations imposed by the state of technology and social organization on the ability of the environment to meet current and future needs (WCED, 1987).

The paradigm of strong sustainable development is also assumed, where some forms of natural capital (environment) are critical and therefore not subject to substitution. The development process that does

\footnotetext{
${ }^{1}$ Among others, regarding the rationality of individuals, full information of economic entities, maximization of utility and profit, consistency of preferences, short time perspective, without taking into account the usability of the environment.

${ }^{2}$ Amorality understood here in the same way as in the book Is capitalism moral? Andre Comté-Sponville (2012) the term amoral refers to concepts that are not subject to moral evaluation, i.e. the judgment on the morality of such objects is ridiculous.

${ }^{3}$ The Oxfam Report (2019) cites data indicating that the number of billionaires almost doubled in the last 10 years. Only in the last year has the wealth of billionaires increased by 900 billion $\$$, which translates into an increase
}

not protect natural capital means entering a path devoid of balance (cf. Mulia, Behura, Kar, 2016).

The widespread assumption about the subjective character of values, the tendency associated with the aspiration to formulate objective laws in economics, led to a general distrust of placing these issues in the area of absolute values, which is debatable and inconsistent with the character of economics, as a social science. Economy without taking into account the real value of natural capital, ignoring the responsibility for the effect of economic activity and consumption, led to the consolidation of the model of a looting economy, the risk of ecological disaster and the emergence of the deepest socio-economic inequalities in history. The production of energy and food, the two most important types of goods that determine the possibility of civilization development is at the same time the area of human activity, generating the largest amount of the so-called external effects ${ }^{4}$. This is evidenced by the report prepared by Trucost PLC (2013), where food production turns out to be the highest in addition to energy obtained from Impact Ratio ${ }^{5}$ coal, as shown in table 1.

The data developed by Will Steffen (et al., 2015) describing 9 planetary boundaries for Earth show that in 4 areas it is already in the area of growing or high risk, and the phenomena described have significant impact on reality. These areas include: biosphere integrity (genetic diversity), biochemical flows (phosphorus and nitrogen), change of land system (changes in structure, quality, soil use) and climate change. Breaking these boundaries is the result of human economic activity, especially agricultural production, which at the same time satisfies the most basic need of nutrition. According to FAOSTAT, in 2015 agricultural areas covered $37.4 \%$ of the Earth's surface, affecting its biodiversity. Disturbances of biochemical flows of nitrogen and phosphorus result from the use of fertilizers in agriculture. The change of the land system is linked to the effects of agricultural production (Steffen et al., 2015). According to the KPMG report (2012, p. 27), food production was characterized by a particularly high level of external effects, calculated on the basis of costs incurred as a result of damage, and estimated at USD 200 billion, which constituted $224 \%$ of sector profit. Relatively

of 2.5 billion $\$$ a day. At the same time, the poorest part of humanity: 3.8 billion people, got poorer by $11 \%$. Wealth is becoming more and more concentrated, in 2018, 26 richest people in the world had the same wealth as 3.8 billion of the poorest people.

${ }^{4}$ External effects are understood as costs resulting from the operation of an economic entity that are transferred to other persons or entities, they arise when the operating entity may transfer some of the costs to persons not participating in the benefits of this activity and not being a party to the transaction.

${ }^{5}$ Impact Ratio - Natural capital cost as a percentage of monetary output (revenue). 
Table 1. Ranking of the sector-areas with the largest negative environmental impact, source: Trucost PLC, (2013), Natural Capital at Risk: The Top 100 Externalities of Business.

\begin{tabular}{|c|c|c|c|c|c|}
\hline $\begin{array}{c}\text { Posi- } \\
\text { tion }\end{array}$ & Sector & Region & $\begin{array}{c}\text { Cost of natural } \\
\text { capital \$ billion }\end{array}$ & Income \$ billion & Impact Ratio \\
\hline 1 & Energy from coal & Eastern Asia & 425,8 & 443,1 & 1 \\
\hline 2 & Livestock and cattle grazing & South America & 353,8 & 16,6 & 18,8 \\
\hline 3 & Energy from coal & North America & 316,8 & 246,7 & 1, \\
\hline 4 & Cultivation of crops & South Asia & 266,6 & 31,8 & 8,4 \\
\hline 5 & Rice cultivation & South Asia & 235,6 & 65,8 & 3,6 \\
\hline
\end{tabular}

low food prices, especially in highly developed countries, are therefore an illusory benefit, being only a shift in costs that are revealed by civilization diseases, loss of biodiversity, pollution of soils, air and water. Pesticides, farm waste, pathological micro-organisms, over-supply of nitrogen and phosphorus pollute the soil and surface waters. In UK research alone, the pesticide water purification process costs 125 million $£, 126$ million $£$ is the cost of biodiversity restoration, 310 million $£$ is the annual cost of neutralizing the effects of oversupply of methane and ammonia from animal production, nitrogen oxides resulting from the use of fertilizers and carbon dioxide emitted while generating energy in agriculture (Pretty, 2007, p. 27). Therefore, the question about the real value of goods that arise as a result of such processes is legitimate.

\section{The concept of value}

Defining values, the way of their existence, realisation and cognition constitute a problem of exceptional complexity. The presentation of the multiplicity of approaches and views would be impossible here, hence selected aspects of axiology will be taken into account. Due to the presence of the notion of value in modern ${ }^{6}$ ethical discourse, in the colloquial understanding, this term is attributed primarily to philosophy. However, unlike in most cases where terminology is of philosophical origin and is taken over by economy ${ }^{7}$, the concept of value arose in the area of economic considerations. Janina Filek writes: Due to the fact that the concept of value was drawn by the philosophers from economy, where the axios meant price (...), it results that at the beginning it served for the material valuation of goods (Filek, 2017). The concept of value is appropriate for many areas - including ethics and economics, which traditionally (though not every time), define value respectively in an intangible and tangible way. What is more, the notion that the tangible value is a threat for intangible values is visible in the moral philosophy: the increase in the strength of money takes place at the price of weakening other values. Therefore, the importance of pragmatic values grows, and the criterion ordering the sphere of axiology becomes the

\footnotetext{
${ }^{6}$ The term values appears in philosophy relatively late. Ancient or medieval philosophy did not ask unequivocal
}

market mechanism, because money gives value to things. In such a world, intangible values become invisible (Filek, 2017). This opinion seems to reflect the vision of the contemporary state of affairs, where short-term profit, increasing consumption, and at the macro level economic growth, are the priorities of society, and their implementation led to degradation of the environment and growing social inequalities, the price of which, also in the strictly material sense, is very high (cf. Wilkinson, Picket, 2011). This is a result of the advantage of a utilitarian approach in economics, the assumption of rational resource allocation, where rationality consists in achieving individual consumer and producer goals. The mechanism is based on the undeniable foundation of personal freedom, which is one of the most important in Western civilization, but is should be added that only if it is accompanied by responsibility; in the case of the supply side, for example: for employees, consumers, proper use of resources, in the case of the demand side: for broadly understood effects of consumer choices. In contrast to the mainstream economy, the sustainable development paradigm takes responsibility, besides freedom. Material (instrumental) and moral (absolute) values do not have to constitute antithesis for themselves, and even the production and consumption of material goods, which takes place in a manner that takes account of the moral dimension, leads to the realisation of the latter. The economy process itself is based on absolute values: trust, cooperation, commitment, etc. The condition for functioning of the market mechanism, in terms of model, is the relation of two entities. The emergence of moral values and their concretisation also takes place in the context of social interaction. Jerzy Hausner emphasizes the importance of the social character and writes: their production (values) takes place in the community. (...) If the community disappears, its perfect world does as well. Individuals or things are not the carriers of values, but communities (Hausner, 2017), in this context he performs the division of values into self-contained: $a b-$ solute, related to subjectivity, which do not require a measure, they are accompanied by direct social and instrumental relations: relative, demanding measures (price) and objectification, which allows them to be

questions about the value of being; it also did not use the concept of value (Stróżewski, p. 12, 1981).

${ }^{7}$ For example, freedom, equality or institutionalism. 
instrumentalised, and the relations that accompany them take place through the goods. The implementation of intrinsic values leads to the creation of good in the moral sense; instrumental - in a material sense, particularly interesting in the theory of economics.

\section{Value theory or price theory?}

The problem of value in the economic theory at the beginning of this science was one of the main areas of reflection. This was at a time when economics was looking for its own path, still in close association with social philosophy and ethics ${ }^{8}$. Considering the problem of the value of the created goods and the way it was expressed was in line with the European/Western tradition of humanistic discourse on values, which never found a consensus on the source on their origin: autonomous or heteronomous, or absolute or relative character. However, while at the level of considerations on absolute values, this dialectic led to the development of pluralism and democracy, with regard to instrumental values understood as goods, which from the $18^{\text {th }}$ century was explained by economists, there was an unwritten consensus after the initial lively discussion, which assumed that a common understanding of the value of the goods and what it represents.

Classical economists considered goods to have an objective value introduced by the means of production, as Adam Smith writes (1937, p. 30-47)), the sum of remuneration of production factors, which manifested itself in a natural price (which may differ significantly from market price of the goods). David Ricardo (1951, p. 30) and Karol Marx (1976, p. 128135) narrowed the importance of means of production to work as the most important element creating value. William Petty, earlier in relation to the classics, considered the land and work as a source of wealth and value: Work is a father and an active principle of well-being, and land is its mother (Petty, 1899 , p. 68). Work, as an active factor, creates a value manifested in the natural price, while the relation of demand and supply creates value and market price. Jean-Baptiste Say acknowledged the cost of production as the lower limit of exchange value, and the utility of the goods determined its upper limit (Say, 1829, p. 11-12, 1960, chap. XV.).

Over one hundred years later, in the 1870 s, the concept of value based on objective premises was abandoned in favour of subjectivist theories. Carl Menger denied the existence of objective value as a trait of the goods. Value is the judgment of an economic operator and does not exist outside of human consciousness and is therefore subjective by nature (Menger, 2013, p. 119). A similar starting point was assumed by William Jevons and Leon Walras, by introducing to their considerations the aspect of the ex-

\footnotetext{
${ }^{8}$ Adam Smith, called the father of economy, called himself a moral philosopher, and the issues of behaviour of entities
}

change process in which the value is concretised. Subjectivity of goods was argued from a different perspective by the neo-institutionalist Clarence Ayers, who divided reality into a price economy and industrial economy, a source of price and technological value, respectively. The statement that something is valuable in the consumer and commercial world - that is, the reference to price values - is the result of the influence of a certain institutional complex, that is here: common views, traditions and customs, hierarchy and social structure. The realisation of such values, referred to by Ayers as pseudo-values, does not translate into the progress of society. In contrast to real values, which criterion of recognition is objective science and technology (Ayers, 1944, p. 226-230). The attempt to reconcile subjectivist and objectivist theories was conducted by Alfred Marshall in the model of market equilibrium (see Figure 1).

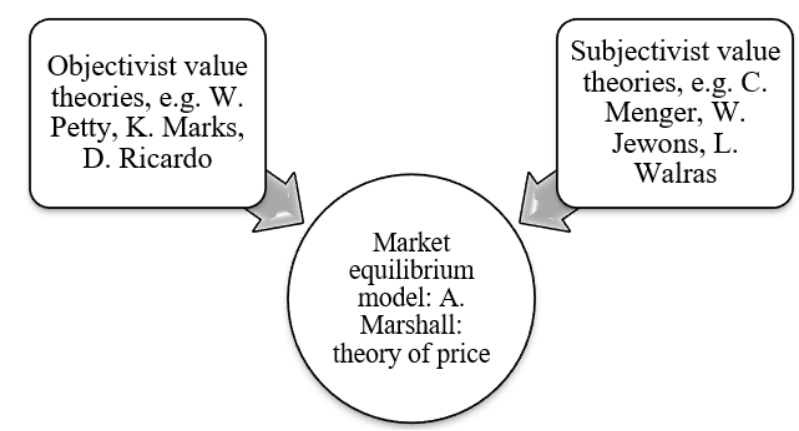

Figure 1. Diagram of the main approaches to the value theory, source: Own elaboration.

Neoclassical synthesis equates the value of goods with the price of market equilibrium. The value of the goods started to be perceived as a relational variable, not the result of the influence of demand or supply factors; the value of the good has become quantifiable. Social and moral aspects of the problems of production and consumption of goods have been eliminated, in favour of quantitative analysis, allowing to determine the price of the given goods (see Giza, 2016). This way of understanding the value of goods has become widely accepted, the theory of price has replaced the theory of values, referring ethical reflection over the economy to a narrow margin, and bringing problems of economic axiology, as in the original meaning of the word, to the price.

Most economists adopted the thesis that the value is expressed in the price, and what has a price also has a value. The classics regarded money as a measure of value, among other things because of its universality as a means of exchange; Ludwig von Mises was willing to give it, at best, the name of a carrier of value, but not a measure, because of their subjective character. However, according to Clarence

on the market and reasons for wealth and misery of nations were placed by him in the sphere of ethical issues. 
Ayers, the price determined in money expresses no more than the subjective utility in the short term. In turn, the value is originally attributable to the goods. Price is a category that occurs only at the time of the sale-purchase transaction, but the value can be discussed regardless of the context. Price is not a measure of value, but only quantifies people's judgments before entering into transactions. It makes something finite and material from value. Also neo-institutionalists, Jonathan Nitzan and Schimshon Bichler claim that the price structure is not related to the material sphere of production and consumption, but because of the inevitable and necessary relations of economy and politics, it quantifies the political power included in prices (Nitzan, Bichler, 2009, p. 9-10).

In the modern economy of fast, mass production and consumption, the price ceased to reflect value, becoming an element of mix marketing. The value of resources and work involved in production is not taken into account or is included partly in the monetary valuation of the goods, which reflects the choices of ordinary people, not necessarily those who are good and smart (Żylicz, 2017). From an ethical perspective, the proposition of pricing the value meets with understandable resistance. The same applies to phenomena that affect the sacrum, moral values, these are considered to be constitutive for a given community, e.g. family, self-determination or freedom; or natural phenomena: the beauty of nature and the unconditionality of its existence from the perspective of man. Talking about the price of nature, respect, honesty and community expressed by the price is perceived as cynicism. Perhaps, however, instead of asking a question about whether the price expresses a value, we need to ask what should be done for it to be so? In a society where the producer expects profit maximization and the consumer maximizes utility, the lack of assigned price, for example in relation to natural resources, results in the fact that something with no price starts being understood as for free, and what is for free is something of no value. Thinkers of the classical period, like from the period of marginalist revolution, did not see the source of values in ecosystem services and the ecosystem itself. The land as a factor of production appears, but its value is paid in the form of pension to its owner and its value is specified in the right of ownership and the possibility of making profits from it. It is understandable that the authors of the above theories formed in the world, which Ernst Ulrich von Weizsäcker and Anders Wijkman call empty (Weizsäcker, Wijkman, 2018, p. 9-12), and which is characterized above all by a significantly lower population and consequently, production and consumption, a world undiscovered and full of natural resources (see Fig. 2).

\section{World population in millions}

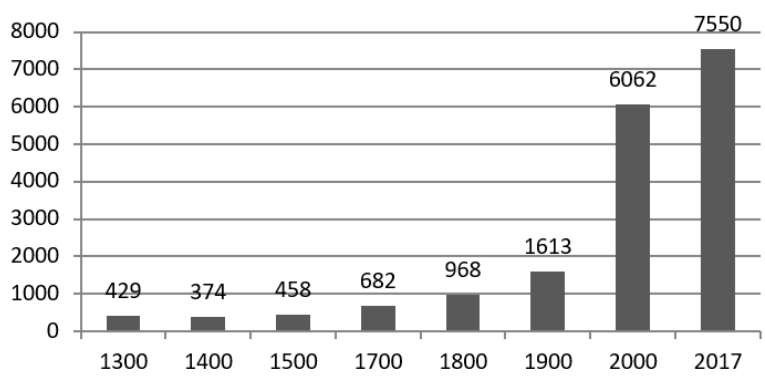

Figure 2. The world population growth in 1300-2017, source: Own elaboration based on: Population Division of the Department of Economic and Social Affairs of the United Nations Secretariat, World Population Prospects: The 2006 Revision and World Urbanization Prospects: The 2005 Revision, United Nations, 2007 and Department of Economic and Social Affairs. Population Division, World Population Prospects: The 2017 Revision, United Nations, New York.

The exponential increase in the population, consumption and exploitation of resources (see Weizsäcker, Wijkman, 2018, p. 17) recorded in the last century, must prompt a review of views on the value of goods in the economy. The criticism of existing value theories was made by Kurt Dopfer, accusing the theory based on work and production costs, the exclusion of natural resources as the actual source of wealth and the unsuitability of the theory in the long run; and the theory of the market price that it does not provide an opportunity to assess the consumption of non-renewable resources and disregards the ecological environment (Dopfer, 1976, p. 3-35). Howard Odum (1995), distinguished two perspectives on speaking about values: from the point of view of the donor - donor-type-values - on which the true well-being depends, taking into account the value of all components needed to create goods or service $^{9}$. On the opposite side, there are values from the point of view of the receiver - receiver-type-values - with an example of the concept of market price (value).

\section{Objective value of the common good}

In the European cultural circle, subjectivism in relations to existential values is an accepted and recognized point of view. At the same time, the superior values shaping this civilization are the slogans of the French Revolution: freedom and equality (see European Parliament, 2018), which in the legal framework, limit the extreme forms of beliefs that could threaten the freedom and safety of other people. In other words, the subjectivity of values is acceptable and recognized, as long as it does not violate the freedom of other entities and does not violate their rights.

\footnotetext{
${ }^{9}$ Here are the value theories based on the means of production.
} 
This approach in relation to the value of goods came down to the licensing of trade in addictive substances, weapons or strategic products. In recent decades, it is more and more often manifested in limiting the production and consumption of goods that generate a high level of negative externalities. This position is expressed in the implementation of emissions quotas and Pigou tax, for example: for plastic bags in Ireland, over-crowding in London, use of coal in Canada, the aim of which is to protect common (objective?) values. It is not the purpose of this article to answer the question about the nature of absolute values, but with respect to instrumental values - material goods and services, the area of objectivity is clear, existing independently of the consciousness of the economic entity. It results from biological determinism. Clarens Ayers writes: Both for each individual and the society, the criterion of value is the continuation of the life process (Ayers, 1944, p. 230), which implies the necessity of supplying the human being with conditions enabling him physical life, and thus clean air, clear water, access to sunlight, lack of extreme temperatures, adequate chemical composition of the biosphere, biodiversity and ecosystem enabling the production of proper food for humans. Classical economists identified these conditions as free goods - not created in the production process and appearing in such abundance that no ownership rights or purchase-sale transactions are assigned to them. David Ricardo writes: you don't pay anything for using water, air and in general the unlimited gifts of nature existing in the unlimited amount (Ricardo, 1913, p. 48). However, today, in the full world, what was considered free, lost the value of unlimited occurrence, more and more often the resources of water, wind energy, clean air, unpolluted ecosystem become private property, the way of their exploitation by some users, limits or prevents their use by others or, in order to use them, it is necessary to incur other costs ${ }^{10}$. Therefore, the Earth's resources have the character of common goods there is an inability to exclude any users with the simultaneous rivalry of consumption. The common goods are characterized by the fact that if they are used too much, the goods can lose their value or be degraded. These common natural goods, contained, used, worn out or destroyed during production process, constitute an objective value of products and services from the point of view of the duration of the human species. Sustainable production makes it possible to preserve or even multiply these goods for the benefit of current and future generations. The re-

\footnotetext{
${ }^{10}$ For example, water wars that have been going on since the dawn of civilization, but nowadays are a particular threat, Ismail Serageldin, former vice-president of the World Bank, said that if wars of this century were fought for oil, the wars of the next one will be fought for water (Serageldin, 2009/2010). The costs of combating air pol-
}

sponsible producer and consumer pay for the production of this type, through internalization, and the price of its products is usually higher.

In the unsustainable production process, when the common good is destroyed, its value is appropriated by the producer and diminished for the rest of society. This kind of producers and consumers agree that the lower price of the produced goods is worth losing some of the common good. Freedom of choice for producers and consumers is an extremely important value. However, this freedom must not be exercised by some consumers and producers in a way which limits the freedom of other consumers and producers, by limiting their access to the common good and dramatically reducing the chances of future generations having equal access to all resources. In the case of destroying or excessive consumption of more tangible common goods - for example transport infrastructure or public space buildings, there is a general agreement that the costs of entities that have contributed to this should be borne by them; in relation to natural common goods, guaranteeing the possibility of biological existence, however, it is less obvious. The economics of sustainable development questions the isolated economic goal of striving to maximize the short-term utility of individuals, which has led to the determination of the source of value in the utility of the producer and the consumer. Searching for and acquiring the value understood in this way contributed to the understanding of development in the narrow scope of increasing the efficiency of production, and from the point of view of the consumer - the level of consumption. The concept of sustainable development, redefining development and its areas, simultaneously identifies sources of value, which is schematically shown in Figure 3.

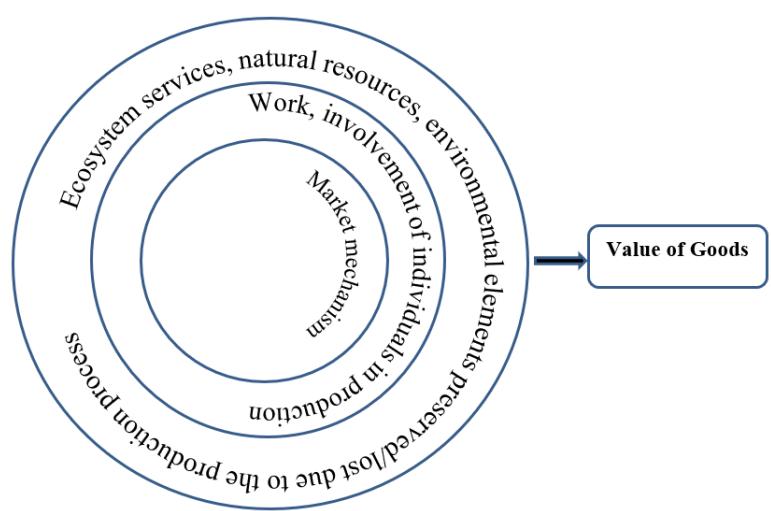

Figure 3. Value of goods in the economics of sustainable development, source: Own elaboration.

lution and the effects of this problem are constantly increasing. Sum of premature deaths from APMP and AOP grew up from 3992722 in year 2000 to 4495142 in 2015, and the cost of these deaths in the OECD group is $3.5 \%$ of the group's GDP (Roy, Braathen, 2017). 
Every area of sustainable development - environmental, social and economic - is reflected in the creation of the value of goods. The subjective value arises as a result of the operation of the market mechanism, which is realised in the market environment. The value of work belonging to the social environment is also a subjective category, depending on how the concept of social justice is understood by the society. It is assumed that the work cannot be slavery, and the pay must be adjusted to the standards of a given economic area ${ }^{11}$, these rules should be reflected in the price of the goods. Finally, the natural environment determines the objective value of the product, which is often not included in the price of the goods. The exclusion of this element reduces the price of production and consumption, at the expense of other members of society and future generations. Consumer goods comprise the value of a lost or preserved environmental common good, an objective value that enables existence. In the current economic model, the preservation of this value is paid for, for example, in the EU policy through subsidies for organic farming or through the internalisation of external costs, for example, through organic crop production and animal husbandry, the production of bioplastics, bio-energy, introduction of circular economy principles and others less aggravating for the environment methods, which lead however to the increase of consumer's prices. The consumer by making a choice, decides to pay for preserving the value of the common good. The payment of a higher price resulting from the preservation of common natural good expresses a social understanding of their value. The higher price of goods, for the production of which the environmental value of which was preserved, may lead to the elitisation of such products, which may be an obstacle to the dissemination of sustainable consumption (see Guthman, 2003; Beagan, Power, Chapman, 2015; Anguelovski, 2015), and in competition with cheaper, unsustainable production, these goods have no chance of dominating the market. With a production burdensome for the environment, the lost value of natural common good is ignored by producers and consumers. External costs resulting from the loss of value of a common good are transferred to the contemporary and future society and are distributed in a random manner. Most producers and consumers do not choose sustainable production methods, which can be understood as transferring the payment/willingness to pay the price for this value in the future. This attitude violates the freedom of choice for future generations and limits access to natural common goods of other subjects. The protection of this freedom may result in the necessity to limit the freedom of the market and the application of systemic fiscal tools, offsetting in the price of the goods the objective value contained within them. The value needs to be understood as a derivative of three areas of sustainable development, which will enable a full implementation of the assumptions of this paradigm. If the production does not burden the environment, its conserved value is expressed in a higher price, for example of organic products. Production that does not take into account the loss of common natural good should be subject to a value lost tax, which leads to the implementation of solutions based on the idea of the Pigou tax or other compensatory tools. The price, which is an expression of the full value, is a safeguard against excessive consumption and production exploiting the environment.

\section{Conclusions}

Elements of the natural environment once considered as free goods, lost the quality of occurring in an unlimited amount and gained the characteristics of common goods, the use of which requires a higher level of responsibility.

The value of goods in terms of sustainable development economics is based on the economic environment that provides a subjective market value; social environment that provides a subjective value of the work; natural environment provides an objective value to the goods. It can be lost or preserved in production process.

The prices are not a measure of value, nor do they express it, as the environmental element is often eliminated from them. The higher price of environmentally neutral/friendly production, contains an element of the preserved value of the environment. The prices of goods produced in a way that is aggravating the environment should be subject to a value lost tax.

\section{Acknowledgments}

The article was created thanks to the NCN grant, Miniatura1.

\section{References}

1. ANGUELOVSKI I., 2015, Healthy Food Stores, Greenlining and Food Gentrification: Contesting New Forms of Privilege, Displacement and Locally Unwanted Land Uses in Racially Mixed Neighbourhoods, in: International Journal on Urban and Regional Research, 39(6).

2. AYERS C.E., 1944, The theory of Economic Progress, University of North Carolina Press, Chapel Hill.

3. BEAGAN B., POWER E. M., CHAPMAN G. E., 2015, Eating isn't just swallowing food: Food prac-

\footnotetext{
${ }^{11}$ These rules are not always implemented, according to Holly Burkhalter, 45 million people suffer from various forms of slavery (cf. Burkhalter, 2017).
} 
tices in the context of social class trajectory, in: $\mathrm{Ca}$ nadian Food Studies / La Revue Canadienne des Études sur l'Alimentation, 2(1).

4. BURKHALTER H., 2017, It's the $21^{\text {st }}$ century. Yet slavery is alive and well, in: The Washington Post, 27.06.2017, https://www.washingtonpost.com/news/ democracy-post/wp/2017/06/27/its-the-21st-centuryyet-slavery-is-alive-and-well/?noredirect=on\&utm term $=.69942728598 \mathrm{~b}(18.02 .2019)$.

5. COMTE-SPONVILLE A., 2012, Czy kapitalizm jest moralny? (Is Capitalism Moral?), Wydawnictwo Czarna Owca, Warsaw.

6. DOPFER K., 1976, Introduction: Towards a New Paradigm, Economy in the Future, Macmillian Publishers Limited, London.

7. EUROPEAN PARLIAMENT, 2018, Respect for the fundamental rights in the European Union, Fact Sheets on the European Union, Unit for Coordination of Editorial and Communication Activities.

8. FAOSTAT, http://www.fao.org/faostat/en/ (20.08. 2018).

9. FILEK J., 2017, Kłopot $\mathrm{z}$ wartościami, (The Problem with Values), in: Zarzadzanie Publiczne (Public Governance). Wartości - normy - dobra (Values norms - goods), Uniwersytet Ekonomiczny w Krakowie, Cracow, 1(39).

10. GIZA W., 2016, O ewolucji ekonomicznej teorii wartości (About the evolution of the economic theory of value), in: Studia Ekonomiczne. Zeszyty Naukowe Uniwersytetu Ekonomicznego w Katowicach, 259.

11. GUTHMAN J., 2003, Fast food/organic food: Reflexive tastes and the making of 'yuppie chow', in: Social and Culture Geography, 4(1).

12. HAUSNER J., 2017, Wartości, normy, dobra, in: Zarzadzanie Publiczne (Public Governance). Wartości - normy - dobra, (Values - norms - goods), Uniwersytet Ekonomiczny w Krakowie, Cracow, 1(39).

13. KPMG, 2012, Expect Unexpected: Building business value in a changing world, Part 2, https://home. kpmg.com/content/dam/kpmg/pdf/2012/08/buildingbusiness-value-part-2.pdf.

14. MARX K., 1976, Capital: A Critique of Political Economy, Volume 1, Harmondsworth, Penguin Books.

15. MENGER C., 2013, Zasady ekonomii (Priciples of Economics), Fijor Publishing, Warsaw.

16. MULIA P., BEHURA A.K., KAR S., 2016, Categorical Imperative in Defense of Strong Sustainability, in: Problemy Ekorozwoju/ Problems of Sustainable Development, 11(2).

17. NITZAN J., BICHLER S., 2009, Capital as a Power: A Study of Order and Creorder, Routledge, London \& New York.

18. ODUM H., 1995, Environmental Accounting: Emergy and Environmental Decision Making, Wiley.
19. OXFAM REPORT, 2019, Public Good or Private Wealth?, Oxfam, Oxford, UK.

20. PETTY, Sir W., 1899, Treatise of Taxes and Contributions, The Economic Writings of Sir William Petty, ed. Hull C.H., Cambridge: Cambridge University Press.

21. PIGOU A. C., 1912, Wealth and Welfare, Macmillian, London.

22. PRETTY J., 2007, Reality Checques, in: Agriculture and Environment, vol. II, Earthscan.

23. RICARDO D., 1913, Zasady Polityki Ekonomicznej $i$ Podatkowania (The Principles of Political Economy and Taxation), Biblioteka Wyższej Szkoły Handlowej, Nakład Gebethnera i Wolfa, Cracow.

24. RICARDO D., 1951, On the Principles of Political Economy and Taxation, ed. by Sraffa, P. with the collaboration of Dobb M., The Works and Correspondence of David Ricardo, vol. I, Cambridge University Press, Cambridge.

25. ROY A., BRAATHEN A.N., 2017, The Rising Cost of Ambient Air Pollution thus far in the 21st Century: Results from BRIICS and the OECD Countries, in: OECD Environment Working Papers, 124, OECD Publishing, Paris.

26. SAY J-B., 1960, Traktat o ekonomii politycznej (A Treatise on Political Economy), Państwowe Wydawnictwo Naukowe, Warsaw.

27. SERAGELDIN I., 2009/2010, Water Wars? A Talk with Ismail Serageldin, in: World Policy Journal, 26(4), Duke University Press, p. 25-31.

28. SMITH A., 1937, The Wealth of Nations, The Modern Library, New York.

29. STEFFEN W. et al., 2015, Planetary boundaries: Guiding human development on a changing planet, in: Science, 347(6223).

30. STRÓŻEWSKI W., 1981, Istnienie i wartość (Existence and Value), Wydawnictwo Znak, Cracow.

31. TRUCOST PLC, 2013, Natural Capital at Risk: The Top 100 Externalities of Business.

32. WCED (World Commission on Environment and Development), 1987, Our Common Future, Oxford University Press, Oxford.

33. WEIZSÄCKER E.U., WIJKMAN A., 2018, Come On! Capitalism, Short-termism, Population and the Destruction of the Planet, A Report to the Club of Rome, Springer Nature, New York.

34. WILKINSON R., PICKETT K., 2011, Duch równości. Tam gdzie panuje równość nawet bogatszym żyje sie lepiej, (The Spirit Level), Wydawnictwo Czarna Owca, Warsaw.

35. ŻYLICZ T., 2017, Wartość ekonomiczna przyrody (Economic value of nature), in: Zarzadzanie Publiczne (Public Governance). Wartości-normy-dobra (Values - norms - goods), Uniwersytet Ekonomiczny w Krakowie, Cracow, 1(39). 